Abstracta Iranica Abstranica

Revue bibliographique pour le domaine irano-aryen

Volume 25 | 2004

Comptes rendus des publications de 2002

\title{
« Der Ayatollah im Netz - offizielle zwölferschiitische Websites ». Orient (Hamburg) 43 (2002), pp. 537-57.
}

\section{Christoph Werner}

\section{(2) OpenEdition}

1 Journals

\section{Édition électronique}

URL : http://journals.openedition.org/abstractairanica/4836

DOI : 10.4000/abstractairanica.4836

ISSN : 1961-960X

Éditeur :

CNRS (UMR 7528 Mondes iraniens et indiens), Éditions de l'IFRI

\section{Édition imprimée}

Date de publication : 15 mai 2004

ISSN : 0240-8910

Référence électronique

Christoph Werner, « «Der Ayatollah im Netz - offizielle zwölferschiitische Websites ». Orient

(Hamburg) 43 (2002), pp. 537-57. », Abstracta Iranica [En ligne], Volume 25 | 2004, document 238, mis en ligne le 15 mars 2006, consulté le 25 septembre 2020. URL : http://journals.openedition.org/ abstractairanica/4836 ; DOI : https://doi.org/10.4000/abstractairanica.4836

Ce document a été généré automatiquement le 25 septembre 2020.

Tous droits réservés 


\section{« Der Ayatollah im Netz - offizielle zwölferschiitische Websites ». Orient (Hamburg) 43 (2002), pp. 537-57.}

\section{Christoph Werner}

1 Islamic organisations are increasingly present in the Internet which they use for various purposes of information, propaganda, self-representation and practical help to the believers in the form of online fatwa-services. Particularly strong are Shiite organisations with many leading Ayatollahs boasting their own websites. Brückner presents and discusses some of the most important ones, including http://www.alislam.org, http://www.wilayah.org, http://islamicfeqh.org, and http://www.alkhoei.org. This is a very useful summary for anybody interested in what is going on in the Shiite cyberspace, and while some of the links might be outdated already, nevertheless offers a highly valuable documentation of a medium that by its nature is not as stable as printed material.

\section{INDEX}

Thèmes : 7. Islam

\section{AUTEURS}

CHRISTOPH WERNER

Freiburg 